\title{
基于均匀化理论的页岩基岩运移机制尺度升级 研究
}

\author{
孙海 ${ }^{1}$, 姚 ${ }^{\text {军 }}{ }^{*}$, YALCHIN Efendiev ${ }^{2}$ \\ 1. 中国石油大学(华东)石油工程学院, 青岛 266580; \\ 2. Department of Mathematics, Texas A \& M University, College Station 77843, USA \\ *联系人, E-mail: RCOGFR_UPC@126.com
}

收稿日期: 2016-12-22; 接受日期: 2017-03-24; 网络出版日期: 2017-06-30

国家自然科学基金(编号: 51490654, 51504276, 51504277, 51234007, 51674280)、国家油气重大专项(编号: 2016ZX05061, 2016ZX05060)、山 东省自然科学基金(编号: ZR2014EEP018, ZR2014EL016)、中央高校基本科研业务费专项资金(编号: 17CX02008A)和青岛市自主创新计划 应用基础研究项目(编号：16-5-1-38-jch)联合资助

\begin{abstract}
摘要基岩孔隙是页岩气藏的主要储集空间. 页岩有机质孔隙和非有机孔隙具有不同的赋存方式和传输机 制: 有机质孔隙存在吸附气、游离气两种赋存方式, 无机质内仅存在游离气, 气体在有机质孔隙存在吸附解吸 和吸附气的表面扩散. 传统的数值模拟方法未考虑页岩基岩内不同孔隙介质储集方式和运移机制的差异性, 未 考虑有机质分布结构特征的影响. 本文基于均匀化理论建立了考虑页岩基岩有机质分布特征和相应运移机制 的尺度升级数学模型, 在小尺度模型中考虑有机质和无机质赋存方式和运移机制的差异性. 数值模拟结果表明, 传统上具有相同宏观运移参数的基岩, 若其有机质分布不同, 采用尺度升级后的宏观模型计算的压力变化和产 量均不同, 必须进行尺度升级才能实现复杂结构分布的页岩基岩模拟的准确性.
\end{abstract}

关键词＼cjkstart页岩气, 均匀化理论, 运移机制, 尺度升级

PACS: 47.56.+r , 51.10.+y, 91.60.Ba, 83.50.-v, 47.11.St

\section{1 引言}

页岩气藏储集空间复杂, 赋存方式多样, 具有多 尺度孔隙结构特征和多储集方式的特点 ${ }^{[1]}$, 流体在不 同尺度空间内流动机制不同 ${ }^{[2-4]}$, 采用单一尺度上的 控制方程和流动模拟方法不能准确揭示复杂页岩气 藏内的流动规律 $(\text { 图 } 1)^{[5]}$.

页岩气藏存在 4 个尺度的储集空间 ${ }^{[1]}$ : 纳米级尺度
的有机质孔隙、微米级的干酪根团和非有机孔隙、介 观毫米级尺度上的微裂缝-基岩、宏观米级尺度上的 水平井和压裂缝.气体在不同的储集空间内运移机制 不同, 所采用的方法也不同. (1) 纳米级有机质孔隙内, 传统的连续性假设不再成立, 达西定律和 N-S方程不 再适用, 需采用分子模拟研究有机质表面的吸附解吸 机制, 直接模拟蒙特卡洛方法(Direct Simulation Monte Carlo, DSMC)或修正的格子Boltzmann方法研究有机

引用格式: 孙海, 姚军, Yalchin Efendiev. 基于均匀化理论的页岩基岩运移机制尺度升级研究. 中国科学: 物理学力学 天文学, 2017, 47: 114612 Sun H, Yao J, Yalchin E. Upscaling of gas transport in shale matrix based on homogenization theory (in Chinese). Sci Sin-Phys Mech Astron, 2017, 47: 114612, doi: 10.1360/SSPMA2016-00531 


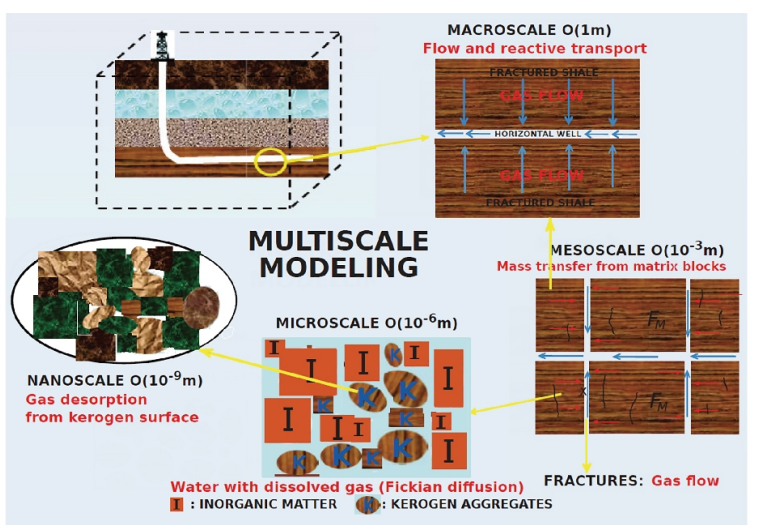

图 1 (网络版彩图)页岩气藏多尺度流动示意图 ${ }^{[5]}$

Figure 1 (Color online) Schema of multiscale flow in shale gas reservoirs $^{[5]}$.

质孔隙内的气体运移. (2) 微米级干酪根团和非有机 质内的运移机制, 根据干酪根团的大小, 可以按两种 方式处理: 若干酪根团和非有机质的尺寸大于表征单 元体(Representative Elementary Volume, REV)尺寸, 则 干酪根团和非有机质内可连续性假设成立, 此时干酪 根和非有机质按连续介质处理 ${ }^{[6]}$, 干酪根内气体考虑 吸附气和游离气两种状态, 考虑气体在干酷根表面的 吸附解吸及吸附气的表面扩散机制、游离气的黏性 流和Knudsen扩散机制; 非有机质内仅考虑游离气的 黏性流和Knudsen扩散机制. 若干酪根团和非有机质 的尺寸小于REV尺度, 则干酪根团和非有机质内连续 性假设不成立, 干酪根和非有机质不能按连续介质处 理, 此时采用修正的格子Boltzmann方法研究干酪根团 和非有机质内的运移气体. (3) 介观毫米尺度上基岩 和微裂缝, 按照微裂缝的分布特征, 微裂缝可按离散 裂缝模型或连续介质模型, 考虑微裂缝与基岩界面自 由流和渗透率的耦合, 建立基岩和微裂缝的等效数学 模型, 研究其运移机理. (4) 宏观米级尺度上, 考虑压 裂缝和水平井内的流动, 压裂㖓采用离散裂缝模型显 示处理, 基质采用连续介质模型或考虑微裂缝的等效 连续介质模型描述.

在精细尺度上能够准确描述流体的运移特征, 但 由于每个模拟方法都有其适用的空间尺度和时间尺 度. 在实际生产过程中, 因计算量的问题, 整个油气藏 区域无法直接采用最精细尺度上的模拟方法进行模 拟. 这样如何在宏观模拟中考虑微尺度特征实现对整 个多尺度区域的准确模拟, 是目前研究的热点和难点. 一般采用逐级尺度升级的方法得到宏观尺度上的控
制方程.

尺度升级的方法有多种 ${ }^{[7]}$, 目前多孔介质中常用的 尺度升级方法为均匀化理论 (Homogenization Theory) 和体积平均法(Volume Averaging Method). 均匀化理 论一般应用在周期性问题, 假定存在宏观和微观两 个尺度, 微观尺度的方程通过双尺度渐进展开得到 宏观尺度上均匀化的方程和参数, 该方法适用的条件 是微尺度空间尺寸相对于宏观尺度必须趋于零. 而 体积平均法一般采用平滑化和空间平均公式进行尺 度升级, 不需要有小尺度假设, 因此不需要假定必须 有两个尺度相差较大的空间,一般在REV尺度上进行 升级.

页岩基岩由有机质和无机质构成, 有机质内存 在吸附气和游离气, 无机质内仅存在游离气, 气体 在有机质和无机质孔隙内运移机制不同(有机质内 存在吸附气的表面扩散), 因此两者的控制方程也不 同. 传统的宏观数学模型中未考虑有机质微观分布 特征及其控制方程的不同, 页岩基岩方程仍按传统 单孔隙基岩进行处理, 本文基于均匀化理论对有机 质和无机质的基岩系统进行升级, 考虑有机质的微观 分布特征, 得到基岩的控制方程, 并进行数值模拟研 究, 分析有机质微观分布对页岩基岩宏观数值模拟的 影响.

\section{2 均匀化理论方法及其计算流程}

\section{1 均匀化理论方法简介}

20 世纪 70 年代, Sanchez-Palencia ${ }^{[8]}$, Bakhvalov $^{[9]}$, Keller ${ }^{[10]}$ 在求解复合材料弹性结构的宏观等效材料 参数及刚度性质时提出了均匀化理论, 随后在材料 科学和固体力学领域得到了广泛的应用. 目前该理 论在多孔介质传质传热问题以及流体力学等领域也 得到了应用 ${ }^{[11-13]}$, 并被称为多尺度均匀化方法. 从数 学角度来看, 均匀化理论是一种极限理论, 它利用渐 进展开式和周期性假设, 用系数是常数或变化缓慢 但解逼近原始解的微分方程来代替系数变化快的原 始微分方程, 目前均匀化理论存在一些比较经典的方 法 $^{[14-17]}$.

均匀化理论假定研究区域是由元胞(Base Cell)在 空间上周期重复而成的(图2), 周期 $\varepsilon$ 和整个研究区域 


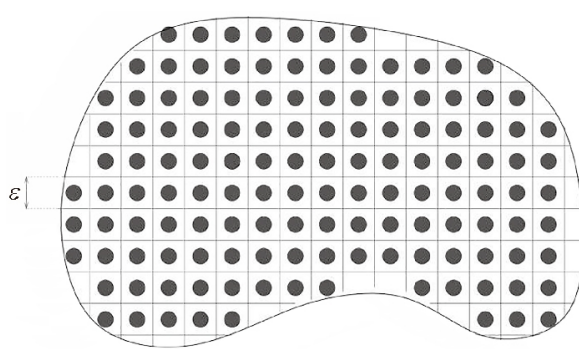

$\Omega_{\varepsilon}$

图 2 周期性的宏观定义域 ${ }^{[18]}$

Figure 2 A periodic domain ${ }^{[18]}$.

相比非常小, 在整个研究区域内对考虑元胞内变化的 方程采用双尺度渐进展开, 可到大尺度上的宏观控制 方程, 宏观控制方程仅为大尺度定义域的函数, 控制 方程的参数与小尺度元胞的属性有关. 通过对元胞问 题进行求解可以求得大尺度宏观控制方程, 然后求解 大尺度控制方程可以求得整个定义域的解.

以稳态问题为例, 假定在整个定义域内满足以下 方程:

$\left\{\begin{array}{cc}-\operatorname{div}\left(A\left(\frac{x}{\varepsilon}\right) \nabla u_{\varepsilon}\right)=f, & \Omega_{\varepsilon}, \\ u_{\varepsilon}=0, & \partial \Omega_{\varepsilon} .\end{array}\right.$

其中, $\boldsymbol{A}$ 为传导率矩阵, $\boldsymbol{x}$ 为大尺度的坐标, $u_{e}$ 为所 求未知数, 可以为速度、压力、温度、应力等, $f$ 为源 汇项. 平均化上述方程的解并且需找定义域上的有效 属性的过程称之为均匀化. 采用渐进展开的方法进行 均匀化, 对上述方程进行渐进展开, 当周期 $\varepsilon$ 趋于 0 , 方 程的解可以写为 $u_{\varepsilon}=\sum_{i=0}^{+\infty} \varepsilon^{i} u_{i}$, 第一项 $u_{0}$ 为所谓均匀化 方程的解, 有效传导矩阵 $\boldsymbol{A} *$ 可以准确求出, 可以证明 $A^{*}$ 为一常数常量, 与边界条件和源项 $f$ 都没有关系. 通 过渐进分析可以证明, 当周期 $\varepsilon$ 趋于 0 时, $u_{\varepsilon}$ 趋近于 $u_{0}$.

\section{2 均匀化理论基本步骤}

假定在小尺度周期元胞内控制方程为式(2):

$B(x, y, c) \frac{\partial c}{\partial t}+\operatorname{div}(A(x, y, c) \nabla c)=g$,

其中, $\boldsymbol{x}$ 为大尺度上的坐标, $\boldsymbol{y}$ 为微观小尺度单元的坐 标, 宏观 $\boldsymbol{x}$ 不包含小尺度单元的信息, $c$ 为所求未知数, 可以为速度、压力、温度、应力等, $\boldsymbol{g}$ 为源汇项.

均匀化理论得到大尺度上升级的控制方程为式(3):
$B^{*}(x, c) \frac{\partial c}{\partial t}+\operatorname{div}\left(A^{*}(x, c) \nabla c\right)=g$,

其中, $B^{*}(x, c), A^{*}(x, c)$ 为均匀化后得到的有效参数, 与 小尺度的信息 $y$ 无关. 所以, 均匀化理论的关键是如何 求得准确的有效均匀化参数. 考虑微观流动的方程可 以与均匀化的宏观方程具有不同的形式, 如考虑微观 流动时可以为基于 $\mathrm{N}-\mathrm{S}$ 方程的, 也可以是基于达西方 程的.

式(3)中 $B^{*}(x, c)$ 比较容易获取, 可由式(4)表示:

$B^{*}(x, c)=\frac{1}{V_{l}} \int_{V_{I}} B(x, y, c) \mathrm{d} y$,

其中, $V_{l}$ 为周期为 $l$ 的元胞的体积, 如图3所示. 均匀化 理论尺度升级的关键是 $A^{*}(x, c)$ 的求取. 其主要计算过 程如下.

(1) 求解稳态时的小尺度元胞方程, 求解得到不同 常数 $c$ 时的速度: 设小尺度方程为 $F_{\text {micro }}(c)=0$. 根据边 界条件的不同, 分别计算不同方向的速度, 并计算整个 区域的平均速度 $\boldsymbol{u}(c)$. 微观模拟中根据物理尺寸和模 拟问题的不同, 可采用不同的模拟方法. 若满足连续 介质假设, 可采用传统的求解连续介质方程的方法求 解; 若尺度较小, 不满足连续介质假设, 可采用孔隙尺 度模拟方法(格子Boltzmann方法、孔隙网络模型等) 或分子尺度模拟方法(分子动力学模拟等)进行求解.

(2) 计算固定参数 $c$ 时的均化参数:

$A^{*}(x, c)=u(c) / \nabla c_{l}$.

(3) 通过改变参数 $c$, 重复 1,2 步, 得到不同 $c$ 下的均 匀化参数表.

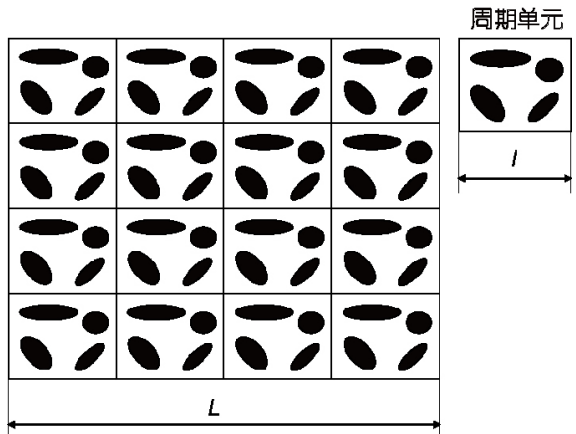

图 3 特征长度为 $L$ 的周期性元胞概念图

Figure 3 The conceptual model of the periodic cell with characteristic length $L$. 
(4) 大尺度上对式(3)进行求解, 方程中的 $B^{*}(x, c)$, $A^{*}(x, c)$ 采用式(4)和(5)计算的均匀化参数表进行插值 得到.

\section{3 基于均匀化理论的基岩数学模型建立}

\section{1 模型的基本假设}

本文研究如何基于页岩微米尺度上有机质和非 有机质的分布, 建立能够表征有机质分布特征的页 岩基岩数学模型. 扫描电子显微镜 (Scanning Electron Microscope, SEM) 扫描研究发现, 如图4所示, 页岩中 有机质以团簇状分布, 有机质可采用连续介质处理, 因此假定微观尺度上有机质和非有机内采用连续介 质模型进行表征 ${ }^{[19]}$.

假定气体在非有机质内仅存在游离气, 考虑黏性 流和Knudsen扩散; 气体在非有机质内存在吸附气和 游离气, 除考虑黏性流和Knudsen扩散外, 还考虑吸附 层厚度和表面扩散对运移机制的影响; 气藏在生产 过程中温度保持不变, 气体在有机质表面的吸附满足 Langmuir等温吸附方程; 页岩气藏中仅存在单相单组 分甲烷气体. 页岩气藏微观上有机质分布为周期性分 布, 如图3所示, 在宏观上为均质储层.

\section{2 数学模型的建立及求解}

\subsection{1 小尺度数学模型}

按照以上假设建立小尺度上数学模型, 如式 6 所示:
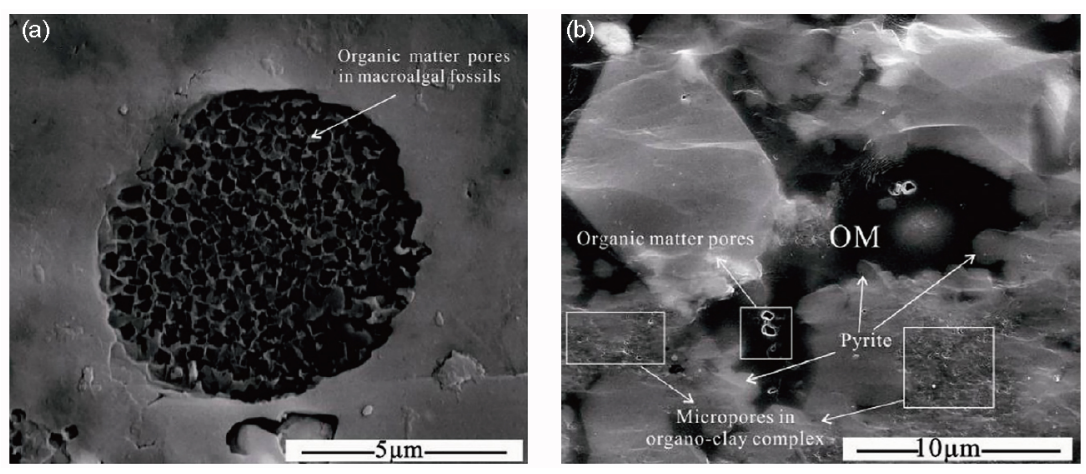

图 4 中国湖南某区牛蹄塘组有机质孔隙分布特征(Wang等人 ${ }^{[19]}$ ). (a) 微化石中的蜂窝状有机质孔隙 $(\mathrm{TOC}=14.2 \%)$; (b) 有机 黏土复合体系中的有机物孔隙 $(\mathrm{TOC}=14.6 \%)$

Figure 4 Organic matter pores in black shales of the Niutitang Formation in Hunan province, China (Wang et al ${ }^{[19]}$ ). (a) Honeycomb organic matter pores of microfossils $(\mathrm{TOC}=14.2 \%)$; (b) organic matter pores in an organo-clay complex $(\mathrm{TOC}=14.6 \%)$. 
$k_{\mathrm{m}, \mathrm{a}, 1}=k_{\infty, 1} f\left(K_{n}\right)+M_{\mathrm{g}} D_{\mathrm{s}} \mu_{\mathrm{g}} \frac{C_{\mathrm{s} \max } P_{\mathrm{L}}}{\left(P_{\mathrm{m}}+P_{\mathrm{L}}\right)^{2}}\left(1-\phi_{\mathrm{eff}}\left(P_{\mathrm{m}}\right)\right)$,

其中 $k_{\infty, 1}$ 为有机质的固有渗透率 $\left(\mathrm{m}^{2}\right), D_{\mathrm{s}}$ 为表面扩散 系数 $\left(\mathrm{m}^{2} / \mathrm{s}\right), C_{\mathrm{s} \text { max }}$ 为吸附气的最大吸附浓度 $\left(\mathrm{mol} / \mathrm{m}^{3}\right)$, $\phi_{\text {eff }}\left(P_{\mathrm{m}}\right)$ 未考虑吸附层后的有效孔隙度 ${ }^{[4]}$.

\subsection{2 大尺度数学模型}

$$
\left\{\begin{array}{l}
\left.B^{*}(x, p) \frac{\partial p}{\partial t}-\nabla \cdot\left[A^{*}(x, p)[\nabla p)\right]\right]=0, \\
\left.p\right|_{t=0}=p_{0}, \\
\left.\frac{\partial p}{\partial n}\right|_{I_{1}}=0 \\
\left.p\right|_{I_{2}}=p_{\mathrm{w}} .
\end{array}\right.
$$

式(9)表示经过均匀化理论尺度升级后的基岩数 学模型, $p_{0}$ 为气藏初始压力 $(\mathrm{Pa}), \Gamma_{1}$ 表示外边界, $\Gamma_{2}$ 表 示内边界, 本文假设外边界条件封闭内边界定压; $B^{*}(x, p)$ 和 $A^{*}(x, p)$ 表示计算的等效参数表, 计算过程 如下.

\subsection{3 等效参数的计算}

给定固定的压力 $p_{i}$, 求解式(6), 然后计算每个方 向的速度:

$V^{*}(x, p i)$

$=\frac{1}{V_{l}} \int_{V_{l}} \gamma\left[\frac{p_{\mathrm{m}}(x, y) k_{\mathrm{m}, \mathrm{app}}(x, y)}{\mu_{\mathrm{m}}(x, y)}\left(\nabla p_{\mathrm{m}}(x, y)_{i}\right)\right] \mathrm{d} y$.

然后计算等效参数 $A^{*}(x, p)$ :

$A^{*}(x, p)_{i}=\frac{1}{\Delta p / L_{i}} V^{*}(x, p i)_{i}$.

\section{最后计算等效参数 $B^{*}(x, p)$ :}

$$
\begin{aligned}
& B^{*}(x, p)= \\
& \frac{1}{V_{l}} \int_{V_{l}}\left[\gamma \phi_{\beta}(x, y, p)+\beta(x, y, p) \frac{\left(1-\phi_{\beta}(x, y, p)\right) M_{\mathrm{g}} p_{\mathrm{L}} V_{\mathrm{L}} \rho_{\mathrm{s}}}{V_{\text {std }}\left(p_{\mathrm{L}}+p_{\mathrm{m}}\right)^{2}}\right] \mathrm{d} y .
\end{aligned}
$$

不断改变 $p_{i}$, 可以计算一系列的等效参数.

\subsection{4 模型求解}

对于大尺度数学模型和小尺度数学模型, 都采用有 限元方程进行求解, 具体求解过程, 参见文献[3,20-23].

\section{4 实例计算及影响因素分析}

为了研究有机质微观分布特征, 对具有 3 种有机质 分布(图5,3种模型具有相同的有机碳含量(Total Organic Carbon, TOC)的孔渗等物性参数, 仅分布不同)页岩基 岩应用均匀化理论进行尺度升级, 并对升级后的基岩 模型进行数值模拟, 模拟井距为 $400 \mathrm{~m}$ 的一口生产井的 生产动态, 如图6所示, 由于井网对称性, 只计算左下角 1/4区域的生产动态. 基本参数如下: 气藏初始压力为 $1.0 \times 10^{7} \mathrm{~Pa}$, 定压生产, 井底压力为 $1 \times 10^{6} \mathrm{~Pa}$, 初始气藏 温度 $323 \mathrm{~K}$, 气体组分 $100 \% \mathrm{CH}_{4}$, 无机质孔隙度为 0.05 , 有机质孔隙度为 0.3 , 有机质密度为 $1400 \mathrm{~kg} / \mathrm{m}^{3}$, 压力 梯度 $=0.0318 \mathrm{MPa} / \mathrm{m}, \mathrm{TOC}=4.695 \%$. Langmuir压力 $p_{\mathrm{L}}$ 为 $1.0 \times 10^{7} \mathrm{~Pa}$, 无机质密度为 $2600 \mathrm{~kg} / \mathrm{m}^{3}$, 甲烷摩尔质量为 $0.016 \mathrm{~kg} / \mathrm{mol}$, 气体压缩因子为 1 , 标准状况下摩尔体积 为 $0.0224 \mathrm{~m}^{3} / \mathrm{mol}$, 井筒半径为 $0.1 \mathrm{~m}$. 有机质和无机质具 有相同的固有渗透率, 固有渗透率为 $10 \mathrm{nD}$, 表面扩散 系数为 $1.0 \times 10^{-7} \mathrm{~m}^{2} / \mathrm{s}$. 计算 3 组不同Langmuir体积下模

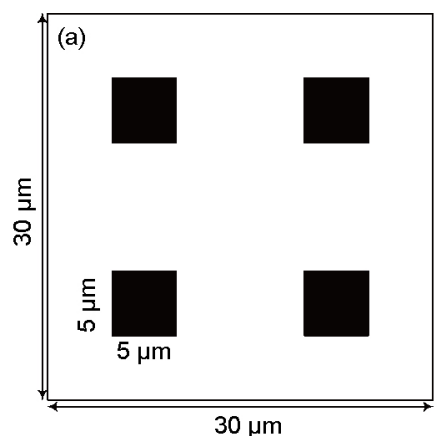

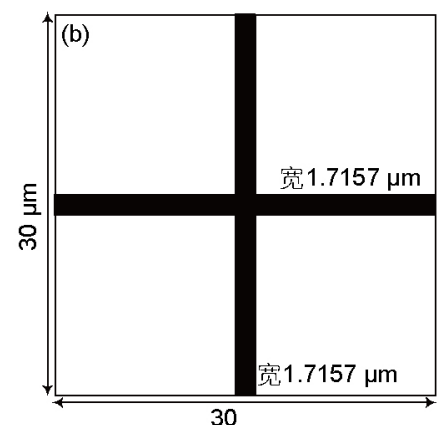

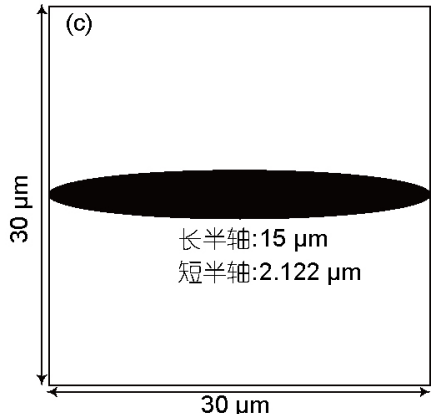

$30 \mu \mathrm{m}$

图 5 页岩有机质微观分布模型. (a) 微观模型 $1 ;$ (b) 微观模型 $2 ;$ (c) 微观模型3 (模型中黑色表示有机质, 白色表示无机质) Figure 5 Micromodel with different organic matter distributions. (a) Micro-model 1; (b) micro-model 2; (c) micro-model 3 (black-organic matter, white-inorganic matter). 


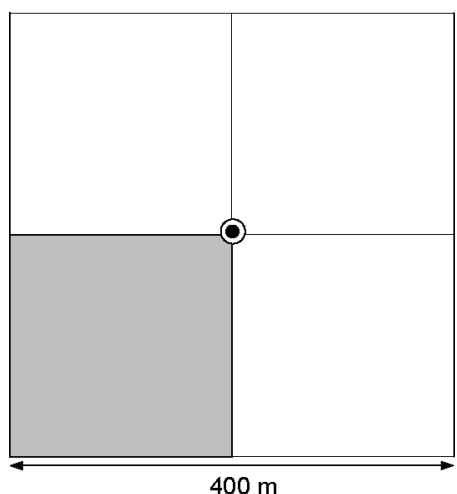

图 6 页岩气生产区域示意图

Figure 6 Segment figure of shale gas production.

拟的结果, Langmuir体积 $V_{\mathrm{L}}$ 分别取 $0.28317,0.14585$ 和 $0.028317 \mathrm{~m}^{3} / \mathrm{kg}$.

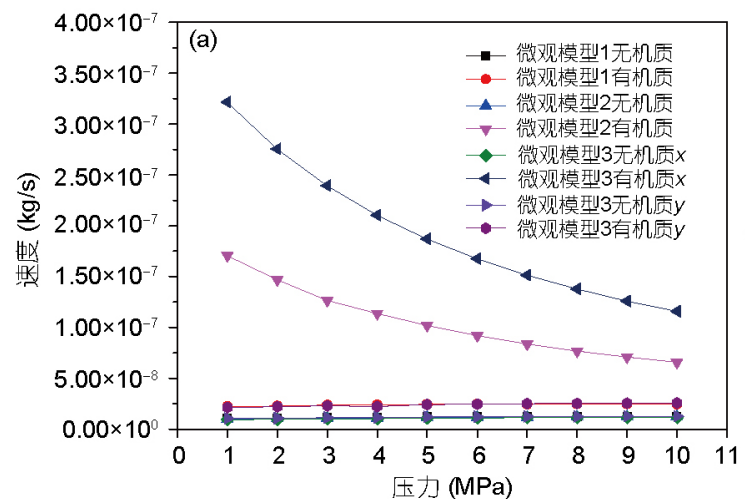

(1) 方案 1: Langmuir体积 $V_{\mathrm{L}}=0.28317 \mathrm{~m}^{3} / \mathrm{kg}$

图7和8表示了当Langmuir体积 $V_{\mathrm{L}}=0.28317 \mathrm{~m}^{3} / \mathrm{kg}$ 时, 不同有机质分布情况下小尺度区域和宏观区域模拟 的结果. 图7表示给定不同压力下,微观模型所计算的 每个方向的平均速度和等效参数 $A$ (式11). 因为微观 模型 1 和 $2 x$ 方向和 $y$ 方向对称, 因此计算的速度和等效 参数 $A$ 在 $x$ 方向和 $y$ 方向是相同的. 由图7(a) 可知, 相同 有机碳含量(TOC)、不同有机质分布情况下, 有机质 的平均速度不同, 且相差较大, 无机质的平均速度基 本相同. 3 种不同微观模型中, 微观模型 3 中计算的 $x$ 方 向的平均速度最大, 微观模型 2 其次, 微观模型 1 最小; 模型 2 和 3 随压力变化较大, 压力越大, 平均速度越小, 而模型1有机质平均速度基本不变; $y$ 方向的渗透率模 型 2 最大, 模型 3 和 1 相差不大.

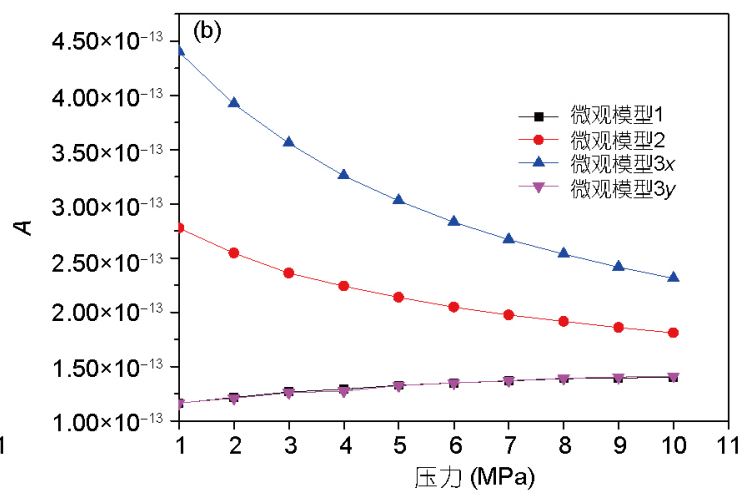

图 7 (网络版彩图)不同压力下小尺度区域的平均速度(a)和等效参数 $A$ (b)

Figure 7 (Color online) The average velocity (a) and effective homogenized parameter $A$ (b) of the local domain at different pressures.
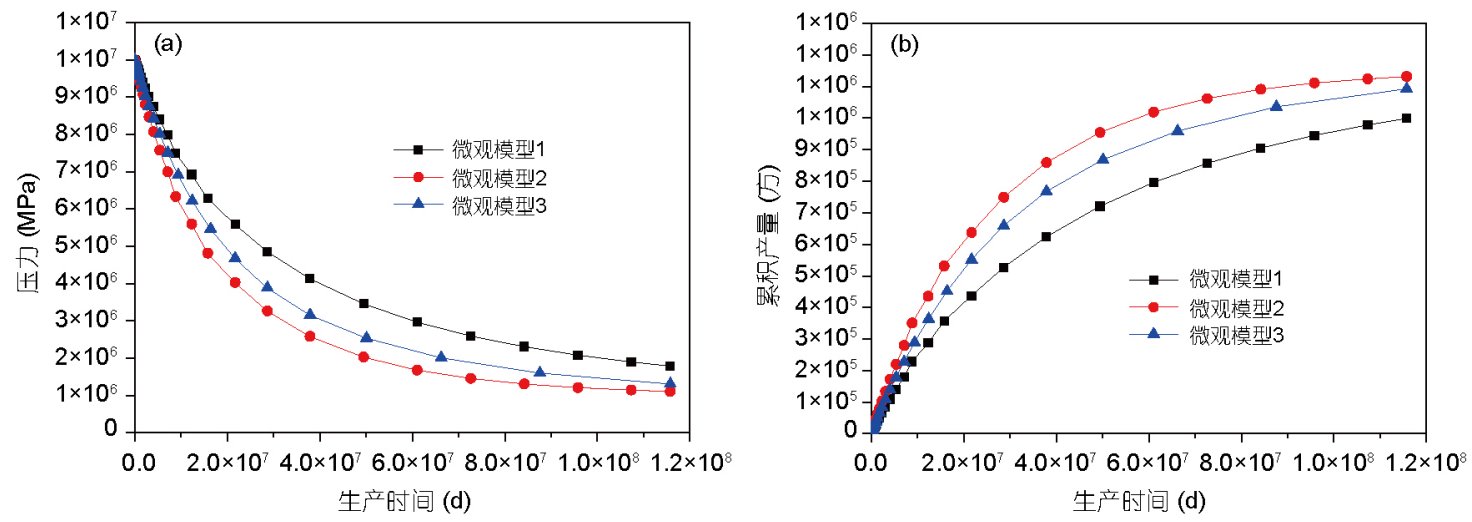

图 8 (网络版彩图)宏观区域的平均地层压力和累积产量随生产时间的变化. (a) 平均地层压力; (b) 累积产量

Figure 8 (Color online) Dynamic variation of the average pressure and cumulative production of the global domain during production. (a) Average pressure; (b) cumulative production. 
图7(b)表示不同压力下计算的等效传导系数 $A$, 由 图可知, 有机质分布如模型 3 时, $x$ 方向的计算的等效 传导系数 $A$ 最大, 模型 2 其次, 模型 1 最小; $y$ 方向的等效 传导系数模型 2 最大, 模型 1 和 3 类似. 因此相同 TOC含 量情况下,有机质的分布对等效传导系数有较大影响.

图8表示了不同有机质分布情况下宏观模型计算 的平均地层压力和累积产量的动态变化, 由图可知, 虽 然 3 个模型具有相同的TOC含量, 相同的物性参数, 但 由于其微观上有机质分布的不同, 考虑有机质分布的 尺度升级宏观模型计算的压力和累积产量不同, 且相 差较大; 而传统的宏观模型, 不考虑有机质分布特征, 不进行尺度升级, 相同宏观参数情况下模拟的开发动 态是相同的. 因此页岩气藏开发过程中应考虑微观的

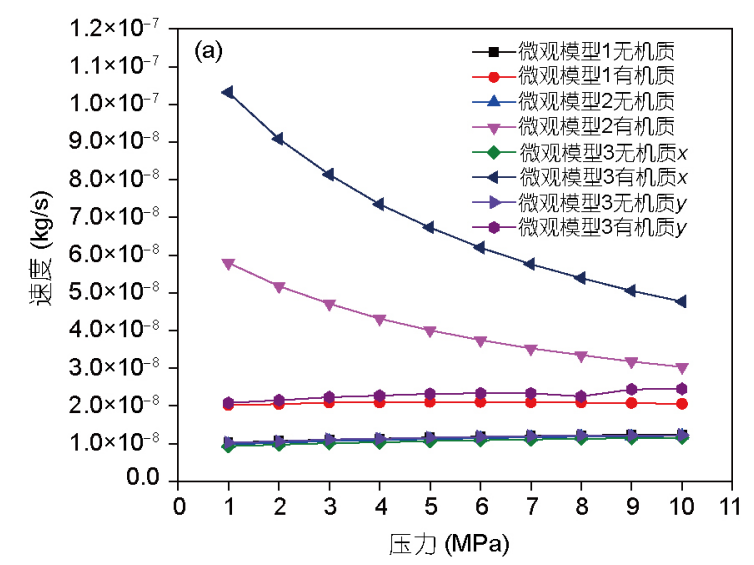

分布特征, 进行尺度升级.

(2) 方案2: Langmuir体积 $V_{\mathrm{L}}=0.14585 \mathrm{~m}^{3} / \mathrm{kg}$

图9和 10 表示了 Langmuir体积 $V_{\mathrm{L}}=0.14585 \mathrm{~m}^{3} / \mathrm{kg}$ 时, 不同有机质分布情况下小尺度区域和宏观区域模拟 的结果, 变化规律与 $V_{\mathrm{L}}=0.28317 \mathrm{~m}^{3} / \mathrm{kg}$ 时基本相同. 通 过有机质分布对开发动态的影响来看, Langmuir体积 越大, 3 种不同微观有机质分布模型的结果差别越大, 可见, 有机质吸附能力越强, 微观有机质分布特征对 开发动态的影响越大.

(3) 方案3: Langmuir体积 $V_{\mathrm{L}}=0.028317 \mathrm{~m}^{3} / \mathrm{kg}$

图11和 12 表示了 Langmuir体积 $V_{\mathrm{L}}=0.028317 \mathrm{~m}^{3} / \mathrm{kg}$ 时, 不同有机质分布情况下小尺度区域和宏观区域模 拟的结果, 对比方案 1 和方案 2 , 此时有机质分布特征对

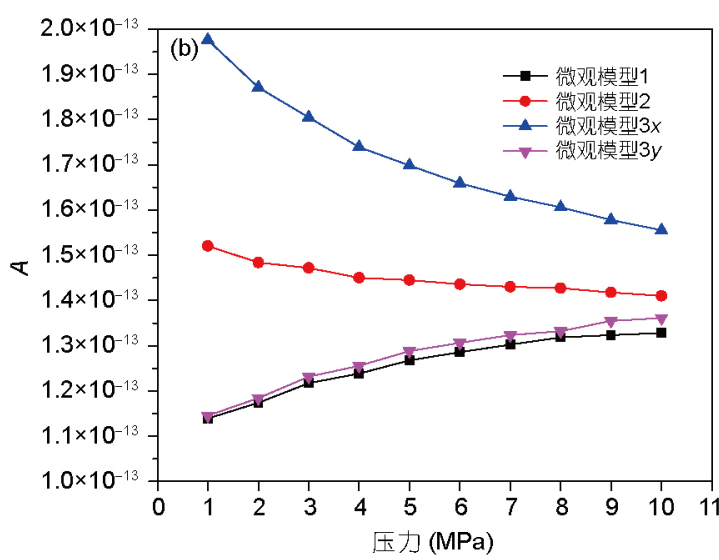

图 9 (网络版彩图)不同压力下小尺度区域的平均速度(a)和等效参数 $A$ (b)

Figure 9 (Color online) The average velocity (a) and effective homogenized parameter $A$ (b) of the local domain at different pressures.
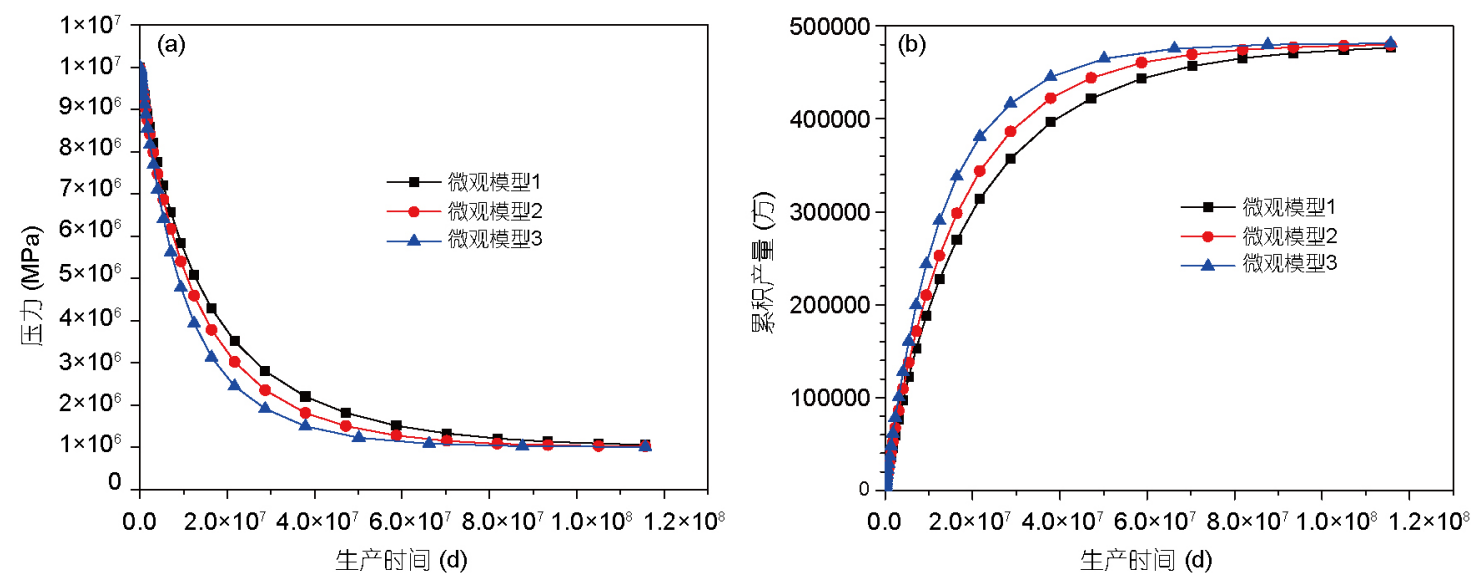

图 10 (网络版彩图)宏观区域的平均地层压力(a)和累积产量(b)随生产时间的变化

Figure 10 (Color online) Dynamic variation of the average pressure (a) and cumulative production (b) of the global domain during production. 

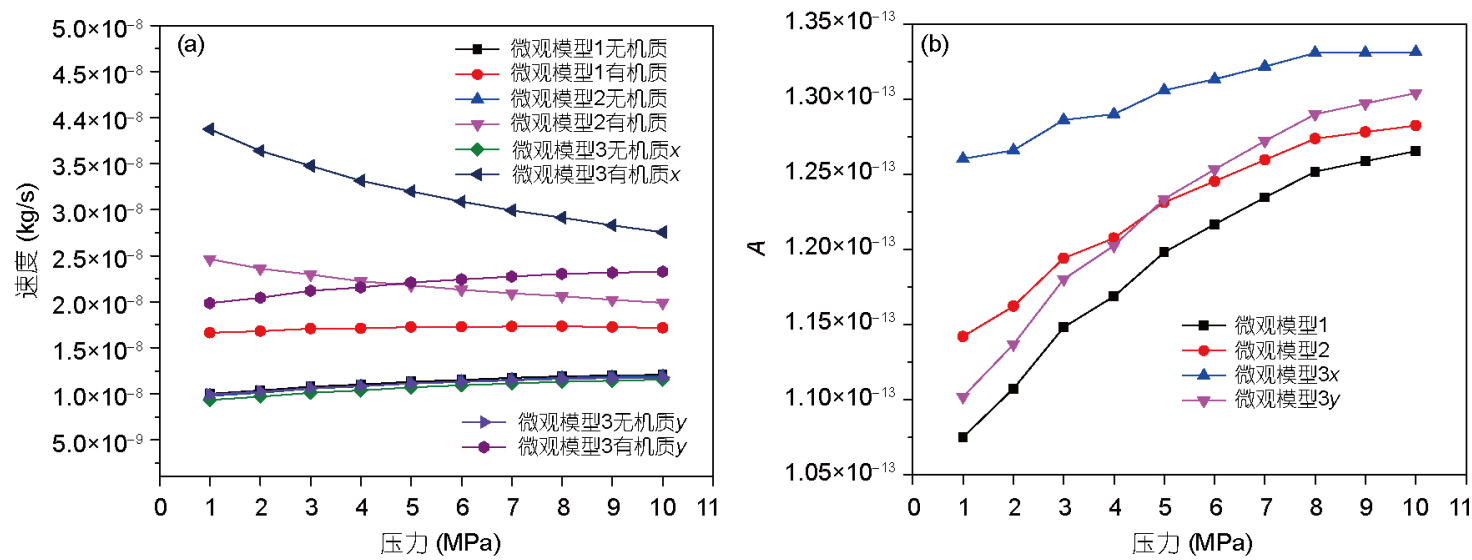

图 11 (网络版彩图)不同压力下小尺度区域的平均速度(a)和等效参数 $A(\mathrm{~b})$

Figure 11 The average velocity (a) and effective homogenized parameter $A$ (b) of the local domain at different pressures.
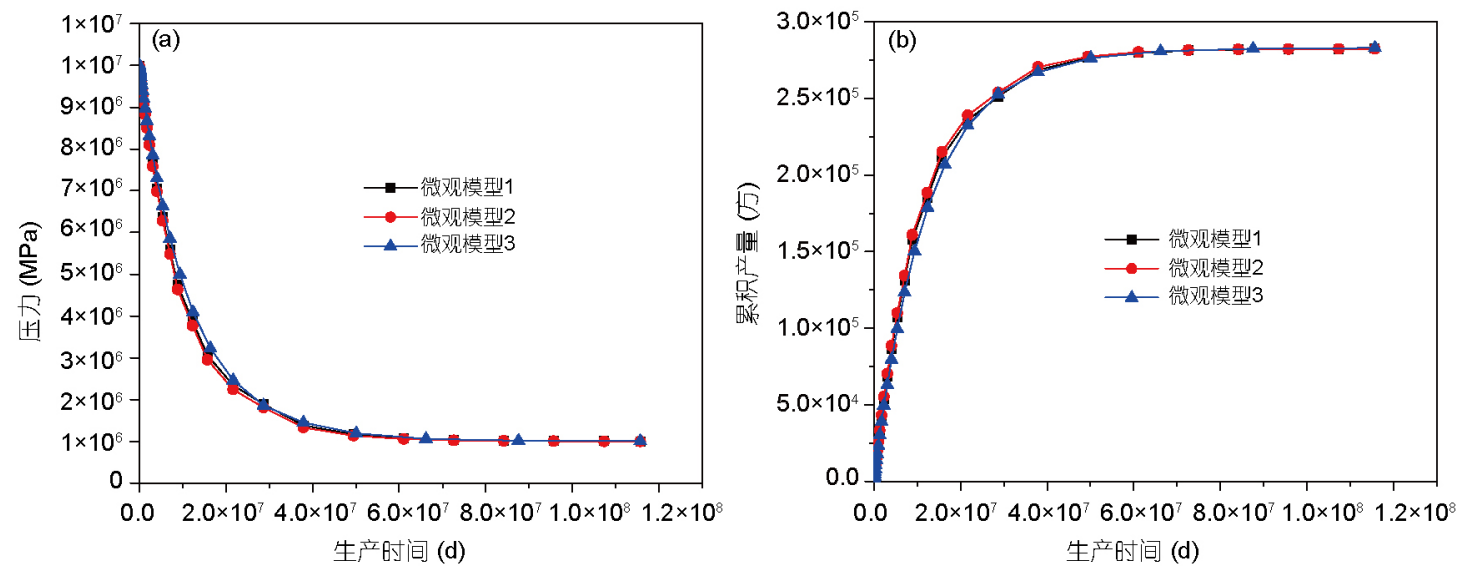

图 12 (网络版彩图)宏观区域的平均地层压力和累积产量随生产时间的变化. (a) 平均地层压力; (b) 累积产量

Figure 12 Dynamic variation of the average pressure and cumulative production of the global domain during production. (a) Average pressure; (b) cumulative production.

开发动态的影响已经非常小了, 因此当吸附能力较弱 时,有机质分布特征对宏观开发动态的影响较小.

\section{5 结论与展望}

本文提出了一种基于均匀化理论的页岩基岩运 移机制尺度升级的方法, 可以考虑页岩基岩中有机质 的微观分布特征对开发动态的影响, 取得的结论和下 一步计划如下: (1) 基于均匀化理论可对微米尺度下 有机质和无机质分布的基质进行尺度升级, 建立考虑
有机质分布特征的尺度升级宏观数学模型. (2) 尺度 升级的宏观数值模拟表明, 相同 TOC含量和宏观物性 特征参数情况下, 有机质分布特征对开发动态具有较 大的影响, 吸附能力越强, 影响越大; 吸附能力较强时, 宏观数值模拟必须考虑有机质微观分布特征进行尺 度升级, 才能准备描述页岩气的开发动态. (3) 目前仅 考虑页岩气藏基岩的尺度升级, 下一步应开展纳米级 尺度-微米级尺度-介观毫米级尺度-宏观米级尺度的 页岩气藏全尺度升级.

\section{参考文献}

1 Yao J, Sun H, Huang Z Q, et al. Key mechanical problems in the development of shale gas reservoirs (in Chinese). Sci Sin-Phys Mech Astron, 
2013, 43: 1527-1547 [姚军, 孙海, 黄朝琴, 等. 页岩气藏开发中的关键力学问题. 中国科学: 物理学 力学 天文学, 2013, 43: 1527-1547]

2 Sun $\mathrm{H}$, Yao J, Gao S, et al. Numerical study of $\mathrm{CO}_{2}$ enhanced natural gas recovery and sequestration in shale gas reservoirs. Int J Greenhouse Gas Control, 2013, 19: 406-419

3 Yao J, Sun H, Fan D, et al. Numerical simulation of gas transport mechanisms in tight shale gas reservoirs. Pet Sci, 2013, 10: 528-537

4 Sun H, Yao J, Fan D, et al. Gas transport mode criteria in ultra-tight porous media. Int J Heat Mass Transfer, 2015, 83: 192-199

5 Murad M, Pereira P, Le T, et al. Bridging between macroscopic behavior of shale gas reservoirs and confined fluids in nanopores. In: Proceedings of the ECMOR XIV-14th European Conference on the Mathematics of Oil Recovery. Catania, 2014

6 Zhang M, Yao J, Sun H, et al. Triple-continuum modeling of shale gas reservoirs considering the effect of kerogen. J Nat Gas Sci Eng, 2015, 24: $252-263$

7 Cushman J H, Bennethum L S, Hu B X. A primer on upscaling tools for porous media. Adv Water Resources, 2002, 25: 1043-1067

8 Sanchez-Palencia E. Comportements local et macroscopique d'un type de milieux physiques heterogenes. Int J Eng Sci, 1974, 12: 331-351

9 Bakhvalov N. Averaged characteristics of bodies with periodic structure. Doklady Akademii Nauk SSSR, 1974, 218: 1046-1048

10 Keller J B. Darcy's law for flow in porous media and the two-space method. In: Proceedings of the Nonlinear Partial Differential Equations in Engineering and Applied Science. Kingston, 1980. 429-443

11 Auriault J L. Heterogeneous medium. Is an equivalent macroscopic description possible? Int J Eng Sci, 1991, 29: 785-795

12 Allaire G. Homogenization and two-scale convergence. SIAM J Math Anal, 1992, 23: 1482-1518

13 Yan X, Huang Z, Yao J, et al. Theoretical analysis of fracture conductivity created by the channel fracturing technique. J Nat Gas Sci Eng, 2016, 31: $320-330$

14 Bensoussan A, Lions J L, Papanicolaou G. Asymptotic Analysis for Periodic Structures. Amsterdam: North Holland Publishing Co., 1978

15 Sánchez-Palencia E. Non-homogeneous media and vibration theory. In: Non-Homogeneous Media and Vibration Theory. Berlin: SpringerVerlag, 1980

16 Panasenko N, Bakhvalov N. Homogenization: Averaging Processes in Periodic Media: Mathematical Problems in the Mechanics of Composite Materials. Dordrecht: Kluwer Academic Publishing, 1989

17 Ene H I, Polisevski D. Thermal flows in porous media. Dordrecht: D. Reidel Publishing Company, 1987

18 Ramaiah H H. Homogenization of Complex Flows in Porous Media and Applications. Dissertation for Doctoral Degree. Palaiseau: Centre de Mathématiques Appliquées, École Polytechnique, 2013

19 Wang Y, Zhu Y, Chen S, et al. Characteristics of the nanoscale pore structure in northwestern hunan shale gas reservoirs using field emission scanning electron microscopy, high-pressure mercury intrusion, and gas adsorption. Energy Fuels, 2014, 28: 945-955

20 Sun H, Yao J, Zhang L, et al. Numerical simulation of gas transport mechanisms in tight shale gas reservoirs (in Chinese). In: The Seventh National Conference on fluid mechanics. Guilin, 2012 [孙海, 姚军, 张否, 等. 致密多孔页岩气体运移机制模拟研究. 见: 第七届全国流体 力学学术会议. 桂林, 2012]

21 Yao J, Sun H, Fan D Y, et al. Transport mechanisms and numerical simulation of shale gas reservoirs (in Chinese). J China Univ Petrol (Nat Sci Ed), 2013, 37: 91-98 [姚军, 孙海, 焚冬艳, 等. 页岩气藏运移机制及数值模拟. 中国石油大学学报(自然科学版), 2013, 37: 91-98]

22 Fan D Y, Yao J, Sun H, et al. Numerical simulation of multi-fractured horizontal well in shale gas reservoir considering multiple gas transport mechanisms (in Chinese). Chin J Theor Appl Mech, 2015, 47: 906-915 [樊冬艳, 姚军, 孙海, 等. 考虑多重运移机制耦合页岩气藏压裂水 平井数值模拟. 力学学报, 2015, 47: 906-915]

23 Yan X, Huang Z, Yao J, et al. An efficient embedded discrete fracture model based on mimetic finite difference method. J Pet Sci Eng, 2016, 145: $11-21$ 


\title{
Upscaling of gas transport in shale matrix based on homogenization theory
}

\author{
SUN Hai ${ }^{1}$, YAO Jun ${ }^{1 *} \&$ YALCHIN Efendiev ${ }^{2}$ \\ ${ }^{1}$ School of Petroleum Engineering, China University of Petroleum (East China), Qingdao 266580, China; \\ ${ }^{2}$ Department of Mathematics, Texas A \& M University, College Station 77843, USA
}

\begin{abstract}
The shale matrix is composed of organic matrix with free gas and adsorbed, and inorganic matrix with only free gas. The gas transport mechanism in two different shale matrix is different. The conventional numerical model did not consider the different gas transport mechanism in the shale matrix and the influence of the distribution of the organic matter. In this paper we established a upscaled shale matrix model with considering these mechanisms. In the microscale region, the Knudsen diffusion and viscous flow of free gas and surface diffusion of adsorbed gas is considered in the microscale model of organic matrix, while only Knudsen diffusion and viscous flow of free gas is considered in the microscale model of inorganic matrix. We calculated the production and pressure of shale matrix have different organic matrix distribution and same TOC content in the microscale region while have same parameters in the macroscale model, the result shows that the macro-scale equations solved directly without homogenization process have the same pressure and production while with upscaling process the solved pressure and production are different in these macro-scale models.
\end{abstract}

shale gas, homogenization theory, transport mechanism, upscaling

PACS: $47.56 .+\mathrm{r}, 51.10 .+\mathrm{y}, 91.60 . \mathrm{Ba}, 83.50 .-\mathrm{v}, 47.11 . \mathrm{St}$

doi: $10.1360 /$ SSPMA2016-00531 